\title{
КОНТРОЛЬ ВХІДНОГО РІВНЯ ЗНАНЬ ЯК ПЕРЕДУМОВА ЕФЕКТИВНОЇ ОРГАНІЗАЦІЇ НАВЧАЛЬНОГО ПРОЦЕСУ НА КАФЕДРІ
}

\author{
S. N. Vadzyuk, S. S. Nakonechna, I. Ya. Papinko \\ I. Horbachevsky Ternopil National Medical University \\ CONTROL OF THE ENTRY LEVEL OF KNOWLEDGE AS A \\ PREREQUISITE FOR THE EFFECTIVE ORGANIZATION OF THE \\ EDUCATIONAL PROCESS AT THE DEPARTMENT
}

\begin{abstract}
Анотація. Контроль знань студентів $€$ важливою частиною процесу навчання як засіб управління навчальним процесом. Вхідний контроль проводиться перед вивченням нового предмета з метою виявлення залишкових знань студентів за дисциплінами, які забезпечують вивчення нового курсу. У статті проаналізовано результати тестування вхідного рівня знань здобувачів вищої медичної освіти для оцінки теоретичної підготовки студентів 2 курсу з подальшим застосуванням як передумови успішної організації вивчення дисципліни. Співробітники кафедри розробили пакети тестових завдань; кожен білет містив 8 запитань, що відповідають основним розділам шкільного курсу біології, а також дисципліни «Фізіологія» (система крові, кровообігу, травлення і виділення, дихання, нервова і гуморальна регуляція функцій організму та сенсорні системи). Аналізуючи отримані результати тестування, було встановлено, що показник успішності (кількість правильних відповідей) у 2021 р. $€$ нижчим порівняно з 2019 р. Зниження загального показника може бути зумовлено запровадженням дистанційної форми освіти у 2020 р. у зв'язку з поширенням пандемії COVID-19. На основі одержаних результатів колективом кафедри розроблені заходи та прийняті відповідні рішення з метою врахування виявлених особливостей, а також подальшого відстеження результатів навчання здобувачів у процесі вивчення дисципліни.
\end{abstract}

Ключові слова: вхідний рівень знань; студенти-медики; тестовий контроль.

Abstract. Control of students' knowledge is an important part of the learning process as a means of managing the learning process. Entry-level assessment is carried out before learning a new subject in order to identify residual knowledge of students in the disciplines that provide the study of a new course. The article analyzes the results of testing the entry level of knowledge of second-year medical students to assess the theoretical training with subsequent use as a prerequisite for successful organization of the discipline. Employees of the department developed packages of test tasks; each ticket contained 8 questions corresponding to the main sections of the school biology course, as well as the discipline "Physiology" (blood, blood circulation, digestion and excretion, respiration, nervous and humoral regulation of body functions and sensory systems). Analyzing the test results, it was found that the success rate (number of correct answers) in 2021 is lower than in 2019. The decline in the overall rate may be due to the introduction of distance education in 2020 due to the spread of Coronavirus disease (COVID-19). Based on obtained the results, the staff of the department developed measures and made appropriate decisions to take into account the identified features, as well as further tracking the learning outcomes of applicants in the process of studying the discipline.

Key words: entry-level of knowledge; medical students; test control.

Вступ. Навчальний процес у вищій школі - це система організації навчально-виховної діяльності, яка складається з цілого ряду елементів, серед яких контроль знань студентів $є$ важливою частиною процесу навчання як засіб управління навчальним процесом [5].

() С. Н. Вадзюк, С. С. Наконечна, І. Я. Папінко
Покращення якості підготовки спеціалістів може бути забезпечене зворотним зв'язком, що реалізується через навчальну діяльність студентів, контроль якої є однією з важливих проблем методичного характеру та компонентом навчального процесу [3].

Поняттям «контроль знань» називають виявлення, вимірювання й оцінку результатів навчально- 
пізнавальної діяльності студентів. Контрольні заходи, які проводяться в університетах, визначають відповідність рівня набутих студентами знань, умінь та навичок вимогам нормативних документів щодо вищої освіти і забезпечують своєчасне коригування навчального процесу. У навчальному процесі використовуються різноманітні види контролю: вхідний, поточний, підсумковий та інші.

Контроль якості результатів навчання - важлива проблема методичного характеру, він сприяє своєчасному виявленню прогалин у знаннях і вміннях студентів, повторенню і систематизації матеріалу, встановленню рівня готовності до засвоєння нового матеріалу, формуванню вміння користуватися прийомами самоперевірки і самоконтролю. Тому посилення уваги до проблеми контролю занять викликане не тільки бажанням визначити ступінь підготовленості студентів, рівень якості викладання, але і потребою удосконалення системи навчання загалом [1, 2].

Вхідний контроль проводиться перед вивченням нового предмета з метою виявлення залишкових знань студентів за дисциплінами, які забезпечують вивчення нового курсу. Це своєрідна діагностика вхідного рівня знань студентів, що застосовується як передумова успішної організації вивчення дисципліни. Проводиться за потреби на початку вивчення окремих навчальних дисциплін для виявлення рівня підготовки здобувачів вищої освіти.

Мета дослідження - провести моніторинг вхідного рівня якості знань здобувачів вищої медичної освіти у Тернопільському національному медичному університеті імені І. Я. Горбачевського МОЗ України для оцінки теоретичної підготовки студентів 2 курсу медичного факультету, які вперше прийшли на заняття на кафедру фізіології з основами біоетики та біобезпеки, маючи вже базовий рівень знань із суміжних дисциплін.

Методи дослідження. 3 метою проведення моніторингу вхідного рівня якості знань студентів 2 курсу медичного факультету, спеціальності 222 «Медицина» на кафедрі фізіології з основами біоетики та біобезпеки Тернопільського національного медичного університету МОЗ України було здійснено вхідний контроль базових знань студентів.

Ми провели тестування студентів 2 курсу медичного факультету у 2019 (218 осіб) і 2021 (247 студентів) навчальних роках на кафедрі фізіології 3 основами біоетики та біобезпеки Тернопільського національного медичного університету.

Вхідний контроль проводився на першому занятті з дисципліни «Фізіологія» за завданнями, що відпо-

відають навчальній програмі предметів, які вивчалися у школі, та протягом першого року навчання в університеті, а саме біології, анатомії та гістології.

Ми розробили пакети тестових завдань; кожен білет містив 8 запитань, що відповідають основним розділам шкільного курсу біології, а також дисципліни «Фізіологія» (система крові, кровообігу, травлення і виділення, дихання, нервова і гуморальна регуляція функцій організму та сенсорні системи) [4, 6, 8].

Кожне завдання оцінювалося за наступною шкалою: правильна відповідь, неправильна відповідь або частково правильна відповідь (неповна); роботи повністю за кількістю правильних, неправильних та неповних відповідей у відсотковому співвідношенні як загалом по курсу (загальна кількість відповідей), так і окремо за основними розділами дисципліни.

Отримані дані вхідного контролю проаналізовані на кафедральних засіданнях спільно з науково-педагогічними працівниками, які проводять заняття 3 дисципліни з метою коригування навчального процесу.

Результати дослідження. За результатами проведених досліджень ми встановили, що у 2019 р. загальна кількість правильних відповідей з усіх розділів загалом по дисципліні становила 45,4 \%, неправильних - 30,1 \%, неповних - 24,5 \% (рис. 1).

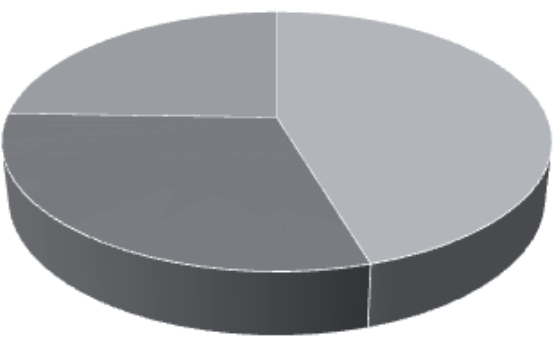

Рис. 1. Вхідний контроль знань у 2019 н. р.

- Кількість

- Кількість

- Кількість неповних правильних відповідей неправильних відповідей відповідей

У 2021 р. загальна кількість правильних відповідей з усіх розділів становить 35,3 \%, неправильних 37,8 \%, неповних - 26,9 \% (рис. 2).

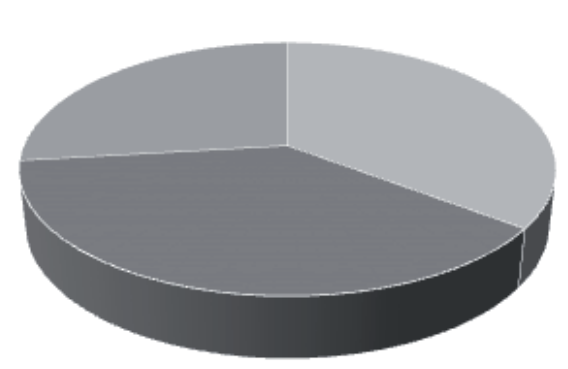

- Кількість правильних відповідей

- Кількість неправильних відповідей

- Кількість неповних відповідей

Рис. 2. Вхідний контроль знань у 2021 н. р. 
Аналізуючи отримані результати тестування 2019 н. р., було встановлено найвищий відсоток правильних відповідей (51,8 \%) - розділ «Серцевосудинна система, кровообіг»; та виявили серйозні недоліки у знаннях з розділу «Автономна нервова система» (48,5 \% неправильних відповідей).

Результати тестування 2021 н. р. продемонстрували найглибші знання студентів з розділів «Автономна нервова система», «Серцево-судинна система, кровообіг» (46 \% та 44 \% відсотки правильних відповідей відповідно), найнижчий відсоток правильних відповідей $(28,4$ \%) з розділу «Кров».

Також проведений аналіз результатів тестування окремо за основними розділами дисципліни.

3 розділу «Кров» у 2019 н. р. встановлено наступні показники: 45,3 \% правильних відповідей, 30,8 \% неправильних відповідей та 23,9 \% неповних відповідей; у 2021 н. р. результати були 28,4 \%, 39,0 \% і 32,6 \% відповідно. Таким чином, з розділу «Кров» було виявлено найнижчий рівень знань у 2021 навчальному році, що враховано викладачами при вивченні та обговоренні тем даного розділу (рис. 3).

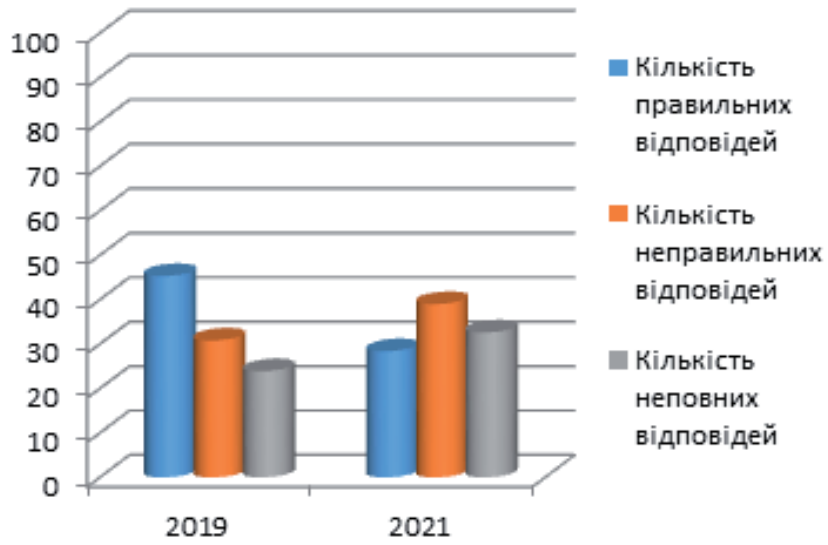

Рис. 3. Вхідний контроль знань 3 розділу «Кров» (2019 та 2021 н. р.).

Нижче наведені результати з розділу «Серцевосудинна система, кровообіг»: 2019 н. р. - 51,8 \% правильних відповідей, 30,8 \% та 17,4 \% неправильних та неповних відповідей; 2021 н. р. - 44,0 \%, 33,5 \% і 22,5 \% відповідно. Отже, результати тестування у 2019 та 2021 навчальних роках показують високий рівень знань (найвищий відсоток правильних відповідей та найнижчий неповних відповідей) вхідного контролю з цього розділу (рис. 4).

Отримані наступні дані тестування з розділу «Травлення і виділення»: 2019 н. р. - 43,7 \% правильних відповідей, 24,7 \% та 31,6 \% неправильних та неповних відповідей; 2021 н. р. - 33,0 \%, 27,0 \% і 40,0 \% відповідно. Таким чином, студенти продемонстрували гірші знання з даної теми у 2021 р.,

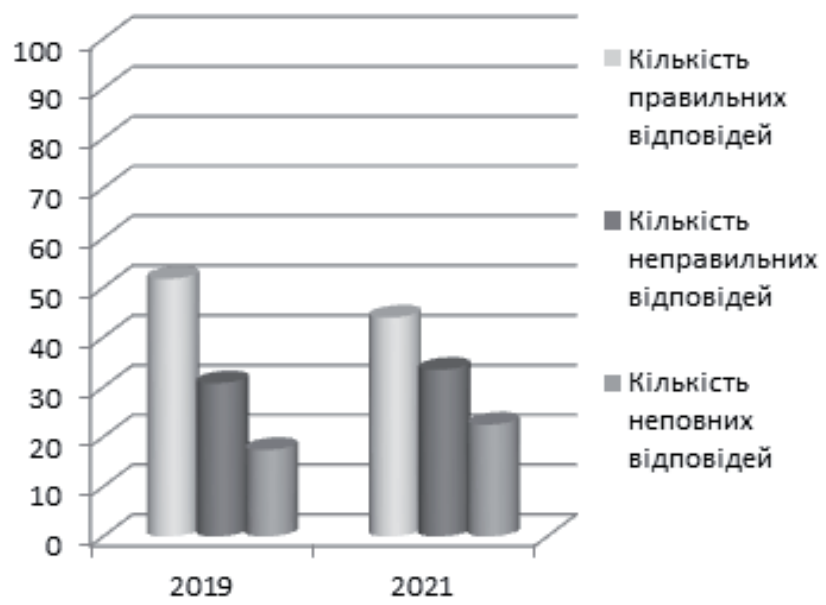

Рис. 4. Вхідний контроль знань з розділу «Серцево-судинна система, кровообіг»

(2019 та 2021 н. р.).

що може бути зумовлено запровадженням дистанційної форми навчання та низькою організованістю студентів (рис. 5).

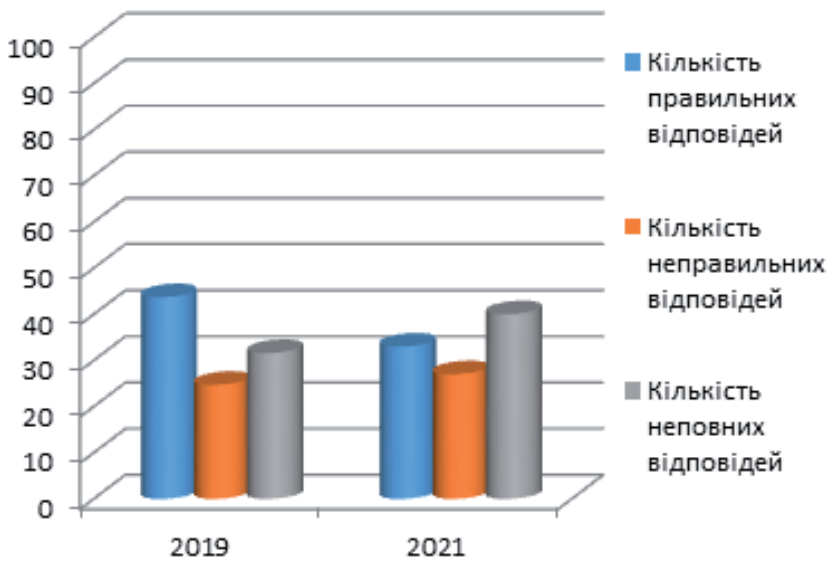

Рис. 5. Вхідний контроль знань з розділу «Травлення і виділення» (2019 та 2021 н. р.).

3 розділу «Дихання» у 2019 н. р. встановлено наступні результати: 49,0 \% правильних відповідей, 30,4 \% неправильних відповідей та 20,6 \% неповних відповідей; у 2021 н. р. результати були 33,0 \%, 40,0 \% і 28,0 \% відповідно (рис. 6). Так, аналіз результатів з даного розділу показав суттєву різницю між показниками 2019 і 2021 років, у 2021 р. кількість правильних відповідей була значно нижчою, а кількість неправильних відповідей зросла.

Результати тестування 3 розділу «Нервова система»: 2019 н. р. - 49,0 \% правильних відповідей, $30,4 \%$ і 20,6 \% неправильних та неповних відповідей; 2021 н. р. - 32,0 \%, 40,0 \% і 28,0 \% відповідно (рис. 7). Отже, у 2021 р. студенти продемонстрували значно нижчий рівень знань 3 даного розділу - відсоток неправильних відповідей суттєво зріс (40,0 \% у 2021 порівняно з 30,4 \% у 2019 н. р.). 


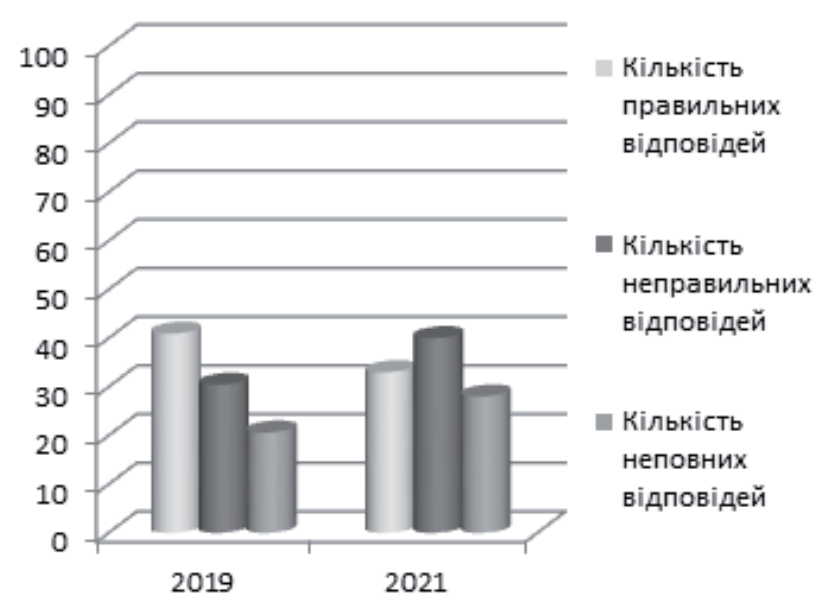

Рис. 6. Вхідний контроль знань з розділу «Дихання» (2019 та 2021 н. р.).

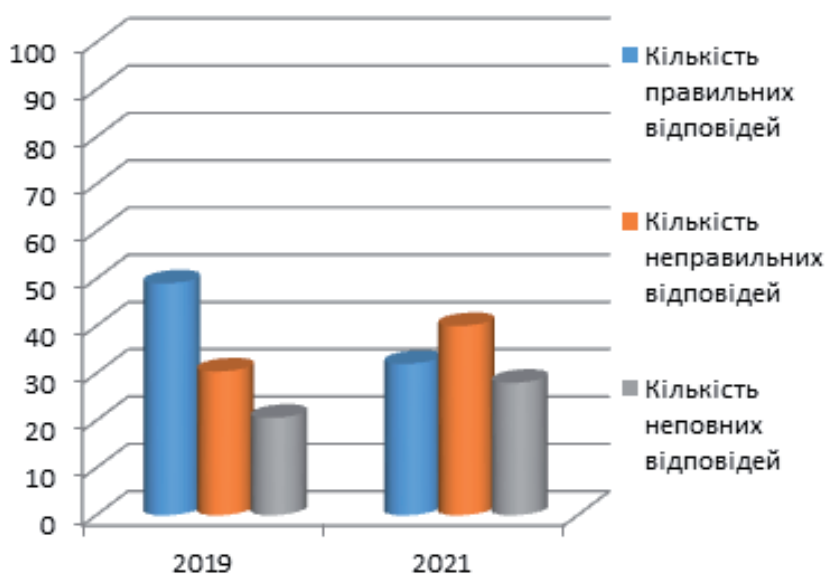

Рис. 7. Вхідний контроль знань з розділу «Нервова система» (2019 та 2021 н. р.).

Аналіз результатів з розділу «Ендокринна система» у 2019 н. р. показав наступні дані: 42,5 \% правильних відповідей, 30,0 \% неправильних відповідей та 27,5 \% неповних відповідей; у 2021 н. р. результати були 34,0 \%, 44,0 \% і 22,0 \% відповідно (рис. 8). Виходячи з отриманих даних, можна зробити висновок, що у 2021 р. показники вхідного рівня знань з розділу були нижчими (відсоток неправильних відповідей значно вищий (44,0% у 2021 порівняно з 30,0 \% у 2019 н. р.).

За одержаними результатами тестування з розділу «Сенсорні системи і вища нервова діяльність» встановлено: 2019 н. р. - 41,7 \% правильних відповідей, 31,7 \% і 26,6 \% неправильних та неповних відповідей; 2021 н. р. - 32,0 \%, 43,0 \% і 25,0 \% відповідно (рис. 9).

Результати тестування з розділу «Автономна нервова система» 2019 н. р. - 38,9 \% правильних відповідей, 48,5 \% і 12,6 \% неправильних та непов- них відповідей; 2021 н. р. - 46,0 \%, 39,0 \% і 15,0 \% відповідно (рис. 10). Таким чином, у 2021 р. встановлено вищий рівень знань вхідного контролю 3 даного розділу, відсоток правильних відповідей був найвищий серед усіх восьми розділів.

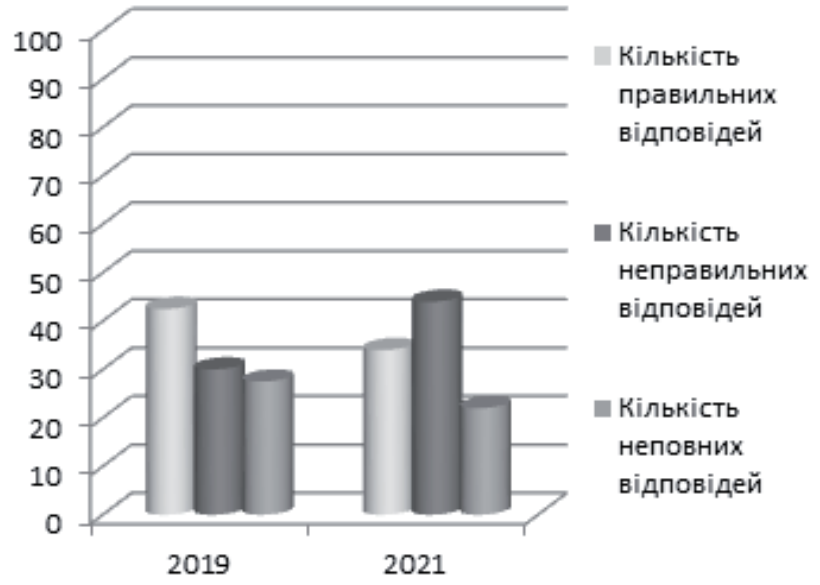

Рис. 8. Вхідний контроль знань з розділу

“Ендокринна система” (2019 та 2021 н. р.).

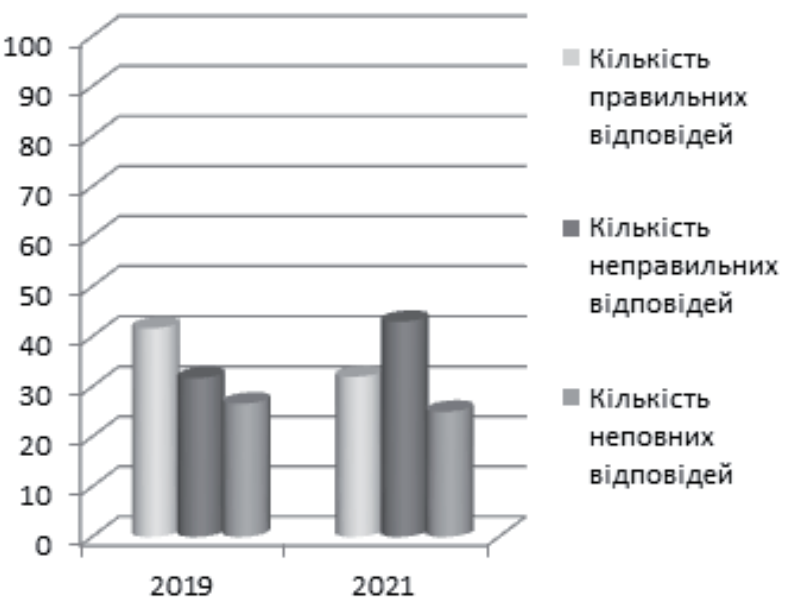

Рис. 9. Вхідний контроль знань з розділу «Сенсорні системи і вища нервова діяльність» (2019 та 2021 н. р.).

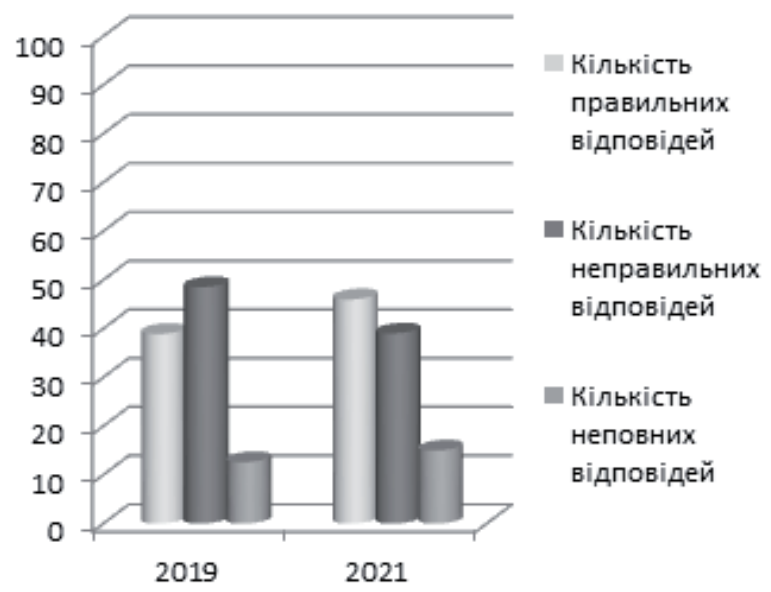

Рис. 10. Вхідний контроль знань 3 розділу «Автономна нервова система» (2019 та 2021 н. р.). 
Відсоток неповних відповідей був найнижчий 3 розділу «Автономна нервова система» у 2019 та 2021 навчальному роках також.

Отримані дані вхідного контролю проаналізовані на кафедральних засіданнях спільно з науково-педагогічними працівниками, які проводять заняття 3 дисципліни з метою коригування навчального процесу.

Ідентифіковано «проблемні розділи» 3 найбільшою кількістю неправильних і/або неповних відповідей. На основі одержаних результатів колективом кафедри розроблені заходи та прийняті відповідні рішення з метою врахування виявлених особливостей, а саме більше уваги приділяється висвітленню теоретичних питань при вивченні даних розділів, самостійна робота студентів, підготовка рефератів, есе з тем, які отримали найнижчу оцінку в процесі тестування, проведення наукових семінарів за участі студентів, підготовка презентацій, розбір тестових завдань типу Крок 1 з розділів із виявленим низьким рівнем знань вхідного контролю, а також подальше відстеження результатів навчання здобувачів у процесі вивчення дисципліни.

Висновки та перспективи подальших досліджень. Проведення вхідного контролю з перевір-

\section{Список літератури}

1. Галузяк В. М. Педагогіка / В. М. Галузяк, М. І. Сметанський, В. І. Шахов. - Вінниця : Логос, 2000. - 200 с.

2. Гарматюк Н. Д. Особливості застосування тестового контролю при вивченні іноземної мови у вищих навчальних закладах / Н. Д. Гарматюк, В. П. Марценюк // Медична освіта. - 2013. - № 3. - С. 17-24.

3. Дівнич Т. Я. Дистанційна форма навчання у вищих навчальних закладах як одна із технологій організації навчального процесу / Т. Я. Дівнич // Медична освіта. 2015. - № 3. - С. 66-69.

4. Саєнко Н. С. Теоретичні аспекти контролю у навчанні іншомовного професійного спілкування / Н. С. Саєнко // Вісник Нац. техн. ун-ту України «Київський політехнічний інститут». Філософія. Психологія. Педагогіка. - 2006. - № 1 (16). - С. 74-78.

5. Тестування як основа кредитно-модульного контролю / С. М. Геряк, І. В. Корда, Н. І. Багній [та ін.] // Медична освіта. - 2010. - № 1. - С. 77-79.

\section{References}

1. Haluziak, V.M., Smetansky, M.I., \& Shakhov, V.I. (2010). Pedahohika [Pedagogy]. Vinnytsya: Lohos [in Ukrainian].

2. Harmatiuk, N.D., \& Martsenyuk, V.P. (2013). Osoblyvosti zastosuvannya testovoho kontrolyu pry vyvchenni inozemnoyi movy u vyshchykh navchalnykh zakladakh ки базових знань студентів 2 курсу медичного факультету 2019 та 2021 навчальних років дозволило зробити такі висновки:

- вхідний контроль - це діагностика наявного вхідного рівня знань студентів, що застосовується як передумова успішного планування та подальшого вивчення дисципліни;

- за підсумками контролю викладачі оцінюють обсяг та рівень теоретичних знань з основ фізіологіï, що дає змогу планувати організацію навчального процесу на кафедрі з урахуванням результатів контролю вхідного рівня знань;

- показник успішності (кількість правильних відповідей) у 2021 р. є нижчим порівняно з 2019 р. Зниження загального показника може бути зумовлено запровадженням дистанційної форми освіти у 2020 р. у зв’язку з поширенням пандемії COVID-19.

Перспективи подальших досліджень - проаналізувати рівень засвоєних знань, умінь і навичок студентів 3 дисципліни «Фізіологія» за результатами здачі екзаменаційної сесії; вивчити думки студентів стосовно можливих шляхів покращення організації навчальних занять; встановити проблемні моменти та можливості їх елімінації.

6. Унгурян Л. М. Застосування тестової системи оцінки знань у навчальному процесі / Л. М. Унгурян, М. С. Образенко // Медична освіта. - 2011. - № 3. C. 20-22.

7. Ястремська С. О. Досвід впровадження дистанційної освіти в Тернопільському державному медичному університеті імені І. Я. Горбачевського / С. О. Ястремська, Л. П. Мазур // Кредитно-модульна система організації навчального процесу у вищих медичних (фармацевтичному) навчальних закладах України на новому етапі : матеріали Х ювілейної Всеукр. навч.-наук. конф. з міжнар. участю (Тернопіль, 18-19 квіт. 2013 р.) / за заг. ред. І. Р. Мисули. - Тернопіль : Укрмедкнига, 2013. - C. 358-361.

8. Sharma S. C. Entry knowledge and situational feedback of MBBS students / S. C. Sharma, S. Maharjan // Kathmandu Univ. Med. J. (KUMJ). - 2005. - 3 (4) (Oct.-Dec.). P. 442-448. PMID: 16449854.

[Peculiarities of test control application at studying foreign language in higher educational institutions]. Medychna osvita - Medical Education, 3, 66-69 [in Ukrainian].

3. Divnych, T.Ya. (2015). Dystantsiina forma navchannia u vyshchykh navchalnykh zakladakh yak odna iz tekhnolohii orhanizatsii navchalnoho protsesu [Distance form of 
education in higher educational institutions as one of the technologies of organization of educational process]. Medychna osvita - Medical Education, 3, 66-69 [in Ukrainian].

4. Sayenko, N.S. (2005). Teoretychni aspekty kontrolyu unavchanni inshomovnoho profesiynoho spilkuvannya [Theoretical aspects of control in teaching foreign language professional communication]. Visnyk Nats. tekh. univ. Ukrayiny «Kyyivskyy politekhnichnyy instytut». Filosofiya. Psykholohiya. Pedahohika - Visnyk of National Technical University of Ukraine "Kyiv Polytechnic Institute”. Philosophy. Psychology. Pedagogy, 1 (16), 74-78 [in Ukrainian].

5. Heryak, S.M., Korda, I.V., \& Bahniy, N.I. (2010). Testuvannya yak osnova kredytno-modulnoho kontrolyu [Testing as a basis of credit-modular verification]. Medychna osvita Medical Education, 1, 77-79 [in Ukrainian].

6. Unhurian, L.M., \& Obrazenko, M.S. (2011). Zastosuvannia testovoi systemy otsinky znan u navchalnomu protsesi [Application of the test system of estimation of knowledges in the educational process]. Medychna osvitaMedical Education, 3, 20-22 [in Ukrainian].
7. Yastremska, S.O., \& Mazur, L.P. (2013). Dosvid vprovadzhennia dystantsiinoi osvity $v$ Ternopilskomu derzhavnomu medychnomu universyteti imeni I. Ya. Horbachevskogo [Experience of introducing distance education in I. Horbachevsky Ternopil State Medical University]. Mysula, I.R. (Ed.). Materialy X yuvileinoi Vseukr. navch.nauk. konf. z mizhnar. uchastiu «Kredytno-modulna systema orhanizatsii navchalnoho protsesu u vyshchykh medychnykh (farmacevtychnomu) navchalnykh zakladakh Ukrainy na novomu etapi» - Proceedings of the $\mathrm{X}$ Anniversary All-Ukrainian Educational and Scientific Conference with International Participation "Credit-transfer system of educational process organization in medical schools (pharmaceutical) of Ukraine at a new stage”. (Vols 1). (pp. 358-361). Ternopil: TDMU [in Ukrainian].

8. Sharma, S.C., \& Maharjan, S. (2005). Entry knowledge and situational feedback of MBBS students. Kathmandu Univ. Med. J. (KUMJ), 3(4) (Oct.-Dec.), 442-448. PMID: 16449854. 